\title{
Differential expression of multiple PR10 proteins in western white pine following wounding, fungal infection and cold-hardening
}

\author{
Jun-Jun Liu, Abul K. M. Ekramoddoullah* and Xueshu Yu \\ Pacific Forestry Centre, Canadian Forest Service, Natural Resources Canada, 506 West Burnside Road, Victoria, British Columbia, \\ V8Z 1M5, Canada \\ *Corresponding author, e-mail: aekramoddoul@pfc.forestry.ca
}

Received 13 January 2003; revised 8 April 2003

\begin{abstract}
Herein the wound-induced expression of a set of PR10 genes (PmPR10) from Pinus monticola (Dougl. Ex D. Don) is described. Thirteen different PmPR10 cDNAs were isolated and their nucleotide sequences were determined from wounded needles. Northern blot analysis showed that PmPR10 gene expression was activated with both local and systemic responses after wounding, and the accumulation of PmPR10 transcript was much more abundant and rapid in wounded needles than in unwounded tissues. Western immunoblot analysis demonstrated that PmPR10 protein synthesis was activated upon wounding, suggesting that the expression of the woundactivated PmPR10 gene was regulated at the transcription level. In wounded needles, the PR10 protein level increased from day 1 to day 8 after treatment. Western immunoblot analysis following
\end{abstract}

isoelectric focusing and two-dimensional electrophoresis revealed that nine PmPR10 proteins accumulated to different extents after wounding. These proteins have a molecular mass of about $18 \mathrm{kDa}$ with different isoelectrical points ranging from 5.2 to 6.0. Woundinducible PmPR10 proteins were differentially expressed in response to cold-hardening and fungal infection. The woundinduced PmPR10 protein accumulation was enhanced by the wound-signal compound methyl jasmonate and okadaic acid, a specific inhibitor of type 1 or type 2 A serine/threonine protein phosphatases. However, it was partially suppressed by salicylic acid and abscisic acid. These data provide an opportunity to elucidate further the signal transduction pathway involved in the activation of PmPR10 protein synthesis in the defence response of white pine against mechanical injury.

\section{Introduction}

Wounding of plants is one of the severest environmental stresses caused by herbivory and parasitism, or by mechanical injury from wind and fire. Wounding can result in the retardation of plant growth and reproduction and the easy penetration of pathogens into plant tissues. Plants respond to wounding with many distinctive biochemical changes through activation of a variety of genes to produce defence-related proteins either in the vicinity of the wounding site alone or in undamaged parts of the wounded plants as well (Bowles 1990, Ryan 1990). The wound-inducible defence-related proteins include pathogenesis-related (PR) proteins, proteinase inhibitors (Peña-Cortés et al. 1989, Farmer and Ryan 1990) and enzymes involved in phenylpropanoid metabolism (Dixon and Païva 1990). The mechanisms underlying the regulation of wound-induced gene expression in plants are complex and not well understood. In plants, jasmonates (Dixon and Païva 1990), abscisic acid (ABA) (Peña-Cortés et al. 1993) and ethylene (O'Donnell et al. 1996) have been shown to be signal compounds for wound-induced gene expression. In Arabidopsis, at least two signalling pathways are activated for wound-induced gene expression: jasmonic acid (JA)independent and JA-dependent pathways (Titarenko et al. 1997). The JA-independent wound-signalling pathway is principally responsible for gene activation in the vicinity of the wounding site, whereas the JA-dependent pathway involves JA perception and activation of gene expression at the wounding site as well as systemically.

Abbreviations - DIG, digoxygenin; IEF, isoelectric focusing; MeJA, methyl jasmonate; OA, okadaic acid; OD, optical density; PAGE, polyacrylamide gel electrophoresis; PR, pathogenesis-related; 5'-RACE, rapid amplification of cDNA end; SA, salicylic acid; SDS, sodium dodecyl sulphate. Authors: Liu, J, Ekramoddoullah, AKM and Yu, X (C) 2003, Her Majesty the Queen in right of Canada, Canadian Forest Service). 
Among the wound-activated PR genes, the PR10 genes encode small, primarily acidic and proteaseresistant intracellular proteins with molecular masses ranging from 15 to $19 \mathrm{kDa}$. PR10 proteins include intracellular PR proteins, tree pollen allergens and major food allergens. They have been reported in a variety of higher plant species, both angiosperms and gymnosperms. In angiosperms, PR10 proteins were found in numerous dicots, such as parsley (Petroselinum crispum) (Somssich et al. 1988), pea (Pisum sativum) (Fristensky et al. 1988), potato (Solanum tuberosum) (Matton and Brisson 1989), white birch (Betula verrucosa) (Breiteneder et al. 1989), bean (Phaseolus vulgaris L) (Walter et al. 1990), soybean (Glycine max cv Mandarin) (Crowell et al. 1992), apple (Malus domestica) (Vanek-Krebitz et al. 1995), celery (Apium graveolens) (Breiteneder et al. 1995) and alfalfa (Medicago sativa) (Breda et al. 1996), as well as several monocots, such as asparagus (Asparagus officinalis) (Warner et al. 1992), rice (Oryza sativa) (Midoh and Iwata 1996), lily (Lilium longiflorum) (Huang et al. 1997) and sorghum (Sorghum bicolor) (Lo et al. 1999). Among gymnosperms, PR10 protein was found in sugar pine (Pinus lambertiana), eastern white pine (Pinus strobus), western white pine (Pinus monticola) (Ekramoddoullah et al. 1995), Douglasfir (Pseudotsuga menziesii) (Ekramoddoullah et al. 2000), white spruce (Picea glauca) (Matheus et al. 2000) and maritime pine (Pinus pinaster) (Dubos and Plomion 2001).

Many PR10 genes have been shown to be expressed during the defence response or after wounding, suggesting their involvement in a general defence mechanism. We have reported a Pin $\mathrm{m}$ III protein associated with cold-hardiness of western white pine (Ekramoddoullah et al. 1995) and subsequent characterization of its cDNA revealed that it belonged to the PR10 gene family (Yu et al. 2000). In the white pine blister rust pathosystem our previous work demonstrated that Pin m III protein was up-regulated following the infection of Cronartium ribicola (Ekramoddoullah et al. 1998). As Pin $m$ III belongs to the PR10 multiple family, and in keeping with the established nomenclature of plant pathogenesisrelated proteins (Van Loon et al. 1994), we hereafter refer to the western white pine genes homologous to PR10 as PmPR10 genes. Our previous work has shown that Pin $m$ III is a member of a highly polymorphic family of PR10 gene in western white pine (Yu et al. 2000). To identify other PR10 genes and to investigate their differential expression in response to environmental stresses, here, we report on PR10 gene expression upon wounding in western white pine.

\section{Materials and methods}

\section{Plant materials and experimental treatments}

Western white pine (Pinus monticola Dougl. Ex D. Don) seedlings were grown in the greenhouse at the Pacific Forestry Centre, Victoria, British Columbia, Canada. Fully developed current-year needles were collected in July and August of 2000 and 2001. For local response after wounding treatments, two methods were used. The first method was to cut the needles from trees at their bottom position and this is referred to as single site wounding. The second method was to crush needles at 3-4 mm intervals with fine forceps and this is referred to as multiple-site wounding. The injured needles were transferred onto $3 \mathrm{MM}$-Whatman paper (Whatman International Ltd., Maidstone, UK) dampened with sterile water in Petri-dishes and incubated at room temperature $\left(22^{\circ} \mathrm{C}\right)$ with normal daily light conditions. For systemic response after wounding treatment, current year branches were cut from the tree, their needles at the lower positions were cut in the middle and the branch was immersed in water. The top unwounded needles were collected to test systemic response. Wounded and unwounded samples were collected at time points indicated on the figures.

For treatments with defence-related signal chemicals and okadaic acid (OA), the multiple-wounded needles were put into test solutions without chemicals (control), or into solutions with chemicals for $30 \mathrm{~s}$, then transferred to the Petri dishes and incubated on moist filter paper dampened with the corresponding test solutions. The following treatments: $100 \mu M$ salicylic acid (SA), $100 \mu M$ abscisic acid (ABA), $1 \mu M$ methyl jasmonate (MeJA), $1 \mu M$ OA were applied. For the low temperature $\left(5^{\circ} \mathrm{C}\right)$ experiment, the seedlings in a growth chamber at $24^{\circ} \mathrm{C}$ with $16 \mathrm{~h}$ light and $8 \mathrm{~h}$ darkness were transferred to a growth chamber at $5^{\circ} \mathrm{C}$ with the same lighting conditions and tissue samples were collected at different times for protein extraction. For each experiment, tissue samples were taken from three different seedlings and frozen in liquid nitrogen and stored at $-80^{\circ} \mathrm{C}$ until analysed.

\section{cDNA cloning of PR10 genes}

To clone PR10 cDNAs induced by wounding, total RNA was extracted from the wounded needles at 0 (control), 4 and 8 days post-treatment. Double-strand cDNA was synthesized using a SMART cDNA library construction kit (Clontech Laboratories, Inc., Palo Alto, CA, USA) following the manufacturer's instructions. A PCR strategy was used for the cDNA cloning of PR10 genes. According to the PR10 cDNA sequence of Pin $m$ III (Yu et al. 2000), two PR10 gene-specific primers (GSP1 and GSP2) were designed at the highly conserved $\mathrm{P}$-loop region and at the $\mathrm{C}$-terminal region, respectively. The primer sequences are: GSP1, 5'-GCC GAC GCC TCC ATC TCC TTG AAG TAA G-3' and GSP2, 5'-C CTC TCC AAT CCC AAC TTA TAC TG- $3^{\prime}$. With primer GSP1 and PCR $5^{\prime}$ primer from the SMART cDNA library construction kit (Clontech Laboratories, Inc.), a 5'-RACE was performed to clone the $5^{\prime}$-end partial sequences of PR10 cDNAs, including the $5^{\prime}$ untranslated region $\left(5^{\prime} \mathrm{UTR}\right)$ and partial coding region of the N-terminal end. A $3^{\prime}$-RACE was performed to clone the $3^{\prime}$ region of the PR 10 gene including the $3^{\prime}$ end untranslated region ( $\left.3^{\prime} \mathrm{UTR}\right)$ and poly (A) tail with primer GSP2 and oligo $(\mathrm{dT})_{30}$. Based on the sequences of $5^{\prime}$ UTR and $3^{\prime}$ UTR clones obtained from 
above $5^{\prime}$ - and $3^{\prime}$-RACE, new primers were designed and synthesized to clone the full length coding regions.

PCR was performed with a PCR Master Mix Kit (Qiagen Inc., Mississauga, ON, Canada) using double strand cDNA as template in a final volume of $50 \mu \mathrm{l}$ on a Perkin-Elmer Themocycler (Perkin-Elmer Applied Biosystems, Foster City, CA, USA). Thermal cycling conditions consisted of an initial denaturation step at $94^{\circ} \mathrm{C}$ for $3 \mathrm{~min}$, followed by 35 cycles of denaturation at $94^{\circ} \mathrm{C}$ for $30 \mathrm{~s}$ and primer annealing and extension at $68^{\circ} \mathrm{C}$ for 3 min, with a final 10 -min extension at $72^{\circ} \mathrm{C}$. After agarose gel fractionation, the amplified DNA fragments with expected sizes were purified and cloned into pGEM-T easy vector (Promega, Madison, WI, USA). Plasmid construction and manipulation were carried out using standard methods (Sambrook et al. 1989).

\section{DNA sequencing and computer analysis}

DNA sequences of PR10 cDNA clones were determined on both strands on an ABI310 DNA sequencer (PerkinElmer Applied Biosystems) using a Thermo-cycle sequence kit (Amersham, Baie d'urfe, Quebec, Canada) with T7, SP6 primer and other internal primers as needed according to the manufacturer's instructions. DNA sequence data were assembled and analysed using BLAST, CluSTALW and ORF finder network services at the National Center for Biotechnology Information (NCBI, Bethesda, MD, USA).

\section{RNA isolation and northern blot analysis}

Total RNA was extracted from western white pine tissues after treatments. Each sample (approximately 0.5-1.0 g) was ground to a fine powder in liquid nitrogen, then homogenized in $10 \mathrm{ml}$ of extraction buffer $(0.1 \mathrm{M}$ Tris$\mathrm{HCl}, \mathrm{pH} 7.4,50 \mathrm{~m} M$ EDTA, $0.5 M \mathrm{NaCl}, 2 \% \mathrm{SDS}, 2 \%$ $\mathrm{PVP}$ and $10 \mathrm{~m} M \beta$-mercaptoethanol). The mixture was incubated for $20 \mathrm{~min}$ at $65^{\circ} \mathrm{C}$. Cellular debris was removed by centrifugation of $12000 \mathrm{~g}$ for $15 \mathrm{~min}$ at room temperature. To the supernatant, $3.3 \mathrm{ml}$ of $5 M \mathrm{KAc}(\mathrm{pH} 5.5)$ was added. The mixture was incubated on ice for $30 \mathrm{~min}$, then centrifuged at $12000 \mathrm{~g}$ for $10 \mathrm{~min}$ at $4^{\circ} \mathrm{C}$. After phenol/ chloroform extraction, the RNA was precipitated from supernatant by adding $1 / 3$ volume of $8 \mathrm{M} \mathrm{LiCl}$ and incubating overnight at $4{ }^{\circ} \mathrm{C}$. The RNA was recovered by centrifugation at $12000 \mathrm{~g}$ for $30 \mathrm{~min}$ and washed with $2 \mathrm{M}$ $\mathrm{LiCl}$ and $70 \%$ ethanol. The air-dried RNA precipitate was re-suspended in $50 \mu \mathrm{l}$ of TE buffer $(10 \mathrm{~m} M$ Tris- $\mathrm{HCl}$, $\mathrm{pH} 7.5,1 \mathrm{~m} M$ EDTA) and kept at $-80^{\circ} \mathrm{C}$ until use. The RNA concentration of individual extracts was determined by UV absorbency and the integrity was checked by agarose gel electrophoresis and ethidium bromide staining.

For northern blot analysis, RNA was denatured by heating at $65^{\circ} \mathrm{C}$ for $10 \mathrm{~min}$ in a formaldehyde gel-loading buffer, $10 \mu \mathrm{g}$ of RNA was separated by electrophoresis on $1.2 \%$ agarose gels containing $7.4 \%$ formaldehyde in morpholinepropanesulphonic acid (MOPS) buffer and transferred to hybond $\mathrm{N}$ membranes (Amersham). The RNA was cross-linked on the blots by UV illumination.
The 3'-UTR region of PmPR10-1.5 was amplified with primers GSP2 and oligo (dT) $)_{30}$ to be used as probe. Our study showed that there were three subgroups of PmPR10 gene family in western white pine (Liu and Ekramoddoullah, unpublished data), PmPR10 cDNAs cloned in this study belonged to a same subgroup. This probe was subgroup-specific and hybridized crossly to different PmPR10 cDNAs cloned in this study, but it did not hybridize to the other two subgroups of the PR10 gene family in western white pine. The probe was labelled with digoxygenin (DIG) using a random primer labelling kit (Boehringer Mannheim, Laval, Quebec, Canada). Pre-hybridization and hybridization were performed at $65^{\circ} \mathrm{C}$ in $0.5 \mathrm{M}$ sodium phosphate buffer $(\mathrm{pH} 7.0), 7 \%(\mathrm{w} / \mathrm{v})$ sodium dodecyl sulphate (SDS) and $1 \mathrm{~m} M$ EDTA (pH 8.0). After hybridization, membranes were washed twice with $40 \mathrm{~m} M$ sodium phosphate $(\mathrm{pH} 7.0)$ and $1 \%$ SDS for $15 \mathrm{~min}$ at room temperature and finally twice at $65^{\circ} \mathrm{C}$ for $30 \mathrm{~min}$. Membranes were exposed to X-ray film for autoradiography. Equal loading and the transfer of RNA were confirmed by monitoring the levels of ribosomal RNA (rRNA) stained with ethidium bromide in agarose gel or with methylene blue on the blots (Sambrook et al. 1989). All northern blot experiments were repeated at least twice.

\section{Western immunoblot analyses}

For western immunoblot analyses, total soluble proteins were extracted from tissues and separated by using SDSpolyacrylamide gel electrophoresis (PAGE), isoelectric focusing, or two-dimensional PAGE. The molecular weight and IEF standard markers were obtained from Bio-Rad (Bio-Rad Laboratories Ltd, Mississauga, ON, Canada). In addition, the recombinant PR10 protein of Pin $m$ III was produced in Escherichia coli and used as a reference marker to determine isoelectric points on IEF gels. After electrophoresis, the separated proteins were transferred onto membranes. The N-terminal regions of putative PmPR10 proteins deduced from cDNA clones of western white pine were almost identical to that of Pin 1 I of sugar pine. The blots were incubated with polyclonal antibodies raised against the $\mathrm{N}$-terminal region of a PR10 protein (Pin 1 I) from sugar pine as reported previously (Ekramoddoullah et al. 1995). The scanning, detection and quantification of the blots were performed with PDI QUANTITY ONE software (Version 3.0, PDI, Huntington Station, NY, USA) according to the instruction manual. The protein level detected by western immunoblot analysis was calculated based on the optical density (OD) of all pixels within the band boundary and expressed in OD units $\times$ millimetre.

\section{Results}

\section{Isolation and characterization of multiple members of PmPR10 gene family from wounded needles}

To characterize PmPR10 gene expression after wounding of western white pine, $5^{\prime}$ - and $3^{\prime}$-RACE was performed 
to amplify the $5^{\prime}$-untranslated region $\left(5^{\prime}\right.$-UTR) and $3^{\prime}$-UTR segments of PR10 cDNA separately. PCR results shown on agarose gels indicated that distinct bands were produced from the tissues of 4 and 8 days post-wounding treatments, but only weak smear products were produced from the 0 days control (Data not shown). Because gene-specific primers (GSP1 and GSP2) were designed at conserved regions of conifer PR10 proteins, the $5^{\prime}$ - and $3^{\prime}$-RACE cloning strategy allowed us to amplify the $5^{\prime}$-UTR or $3^{\prime}$-UTR fragments from multiple gene family members. The amplified fragment mixtures were then cloned for sequence analysis to identify individual PmPR10 gene fragments. DNA sequence analysis subsequently showed that more than $90 \%$ of all cloned fragments encoded an authentic PR10 protein as determined by the deduced amino acid sequence comparison. Using $5^{\prime}$ UTR primer combined with $3^{\prime}$-UTR primer or oligo (dT) 30, full-length coding regions of individual PmPR10 genes were cloned. We identified 13 different wound-inducible PmPR10 cDNAs from 59 clones, designated as PmPR10-1.1 to PmPR10-1.13, indicating the presence of multiple wound-inducible PR10 genes in western white pine (Fig. 1). Among them, the nucleotide sequence of PmPR10-1.10 was identical to Pin $m$ III cDNA except for the absence of 11 nucleotides at the beginning of Pin $m$ III (Yu et al. 2000). We have cloned and sequenced the genomic DNAs of PmPR10-1.10 and PmPR10-1.13 (Liu and Ekramoddoullah, unpublished data) and found that they also lacked the sequence of these 11 nucleotides, suggesting that it might be a cloning artifact in Pin $m$ III.

Southern blot analysis using probe of full-length cDNA of Pin $m$ III (PmPR10-1.10) showed at least seven bands after digestion of genomic DNA with restriction enzyme $X b a \mathrm{I}(\mathrm{Yu}$ et al. 2000). When a 3'-UTR probe of PmPR10-1.5 was used on Hind IIIrestricted DNA, at least six bands were detected (Data not shown). These results allow us to conclude that a multiple family of PmPR10 genes is present in the genome of western white pine and several genes or allelic variants of the PmPR10 gene family were expressed in the wounded needles of western white pine. All 13 cDNA

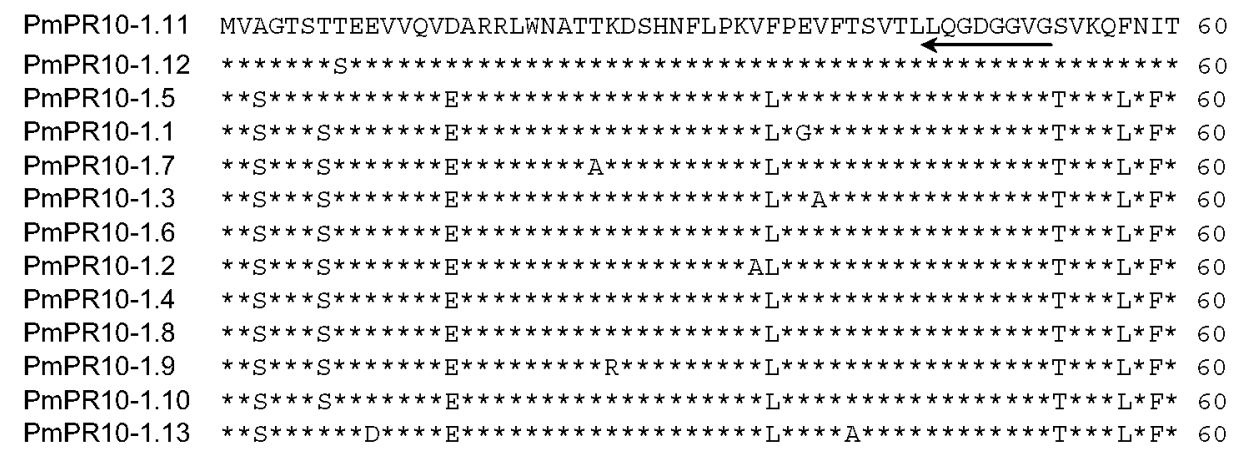

PmPR10-1.11

PmPR10-1.12

PmPR10-1.5

PmPR10-1.1

PmPR10-1.7

PmPR10-1.3

PmPR10-1.6

PmPR10-1.2

PmPR10-1.4

PmPR10-1.8

PmPR10-1.9

PmPR10-1.10

PmPR10-1.13

PmPR10-1.11

PmPR10-1.12

PmPR10-1.5

PmPR10-1.1

PmPR10-1.7

PmPR10-1.3

PmPR10-1.6

PmPR10-1.2

PmPR10-1.4

PmPR10-1.8

PmPR10-1.9

PmPR10-1.10

PmPR10-1.13

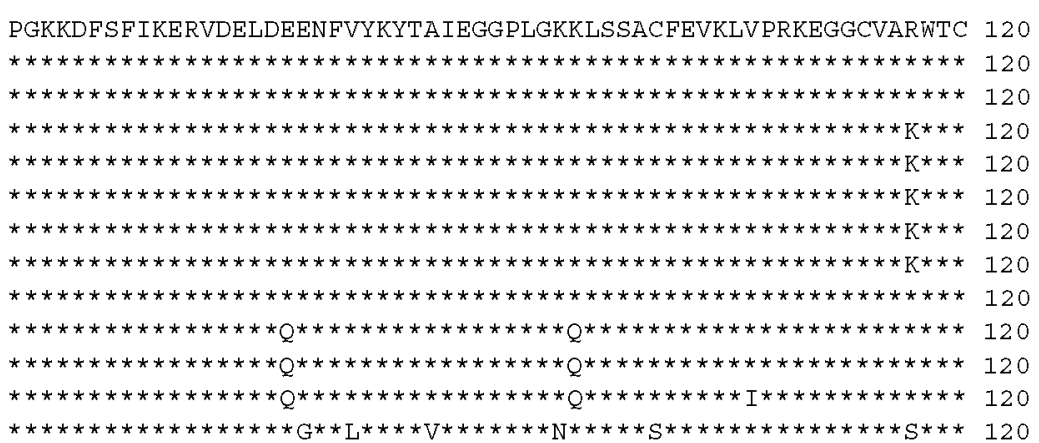

NYDTLPGFQPDEGKLKEIKEDSFGMLKKVEQYLLSNPNLYC 161

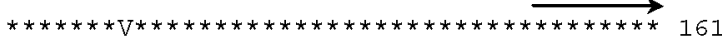

$* * \mathrm{E} * * * * \mathrm{~V}^{*} * * * * * * * * \mathrm{M} * * * * * * * * * * * * * * * * * * * * * * * 161$

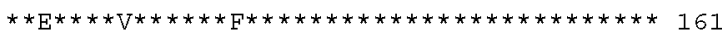

$* * \mathrm{E}^{* * * *} \mathrm{~V} * * * * * * \mathrm{~F} * * * * * * * * * * * * * * * * * * * * * * * * * * 151$

$* * \mathrm{E} * * * * \mathrm{~V} * * * * * * \mathrm{~F} * * * * * * * * * * * * * * * * * * * * * * * * * \mathrm{~F} 161$

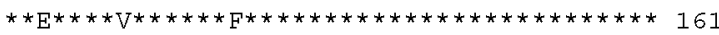

$* * \mathrm{G} * * * * \mathrm{~V} * * * * * * \mathrm{~F} * * * * * * * * * * * * * * * * * * * * * * * * * * 161$

$* * \mathrm{E} * * * * \mathrm{~V} * * * * * * \mathrm{~F} * * * * * * * * * * * * * * * * * * * * * * * * * * 161$

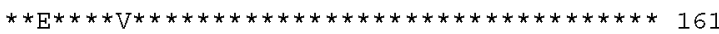

$* * \mathrm{E} * * * * \mathrm{~V} * * * * * * * * * * * * * * * * * * * * * * * * * * * * * * * * * 161$

$* * \mathrm{E}^{* * * *} \mathrm{~V} * * * * * * * * * * * * * * * * * * * * * * * * * * * * * * * * * 161$

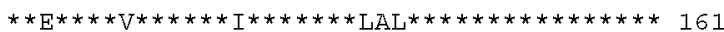

Fig. 1. Alignment of the deduced amino acid sequences derived from 13 PmPR10 cDNAs from wounded needles of western white pine. The amino acid sequence PmPR 10-1.10 is identical to that of the previously published Pin $\mathrm{m}$ III protein. Amino acids identical to the PmPR10-1.11 sequence are represented by asterisks. The positions of PCR primer GSP1 and GSP2 are indicated by arrows at the P-loop and Cterminal regions, respectively. The cDNA sequences have been deposited in GenBank (accession no. from AY064193 to AY064205). 
clones contain a complete open reading frame encoding a polypeptide of 161 amino acids. The deduced amino acid sequences have significant homology to the PR 10 proteins from angiosperms and other gymnosperms and contain the conserved amino acids characteristic of the PR10 gene family. The conserved P-loop region (GXGGXGXXK) is located at positions 47-55 (Fig. 1) and is considered as the possible phosphate-binding site necessary for ribonucleolytic activity (Bantignies et al. 2000). The differences among the 13 PmPR10 genes are found in both $5^{\prime}$ - and $3^{\prime}$ UTR, as well as in the coding region. In the coding region some of the nucleotide changes appear to be silent, but some result in changes of amino acids (Fig. 1). The identities among the PmPR10 protein sequences deduced from these 13 cDNAs range from 87 to $99 \%$. The molecular masses of the putative PmPR10 proteins are at about $18 \mathrm{kDa}$, but their theoretical isoelectric points $(\mathrm{pI})$ ranged from 5.30 to 5.94 , making it possible to distinguish them on IEF gel (Table 1).

\section{Accumulation of the PmPR10 gene transcript in response to wounding}

Northern blot analyses were conducted to monitor the expression of PmPR10 mRNA in a time course after wounding treatments. Both locally wounded needles with multiple injury sites and unwounded needles in the systemically wounded branches were harvested at various times for total RNA isolation. In the wounded needles for local response, a PmPR10 transcript, approximately $0.9 \mathrm{~kb}$ in size, was undetectable in the control needles and needles harvested 1 and $4 \mathrm{~h}$ after wounding, but began to accumulate $8 \mathrm{~h}$ after wounding (Fig. 2A). The transcripts of PmPR10-1.5 and related PmPR10 genes reached a maximum level after 1 day and remained steady up to 8 days after wounding.

Table 1. PR10 genes from wounded needles of western white pine. Data were calculated from the deduced amino acid sequences of the wound-inducible PR10 cDNAs using Expert Protein Analysis System (ExPASY) of the Swiss Institute of Bioinformatics (http:// www.expasy.ch/tools/). ${ }^{\mathrm{a}} \mathrm{MM}$, predicted molecular mass of the polypeptide encoded by the PmPR 10 cDNA clones. ${ }^{b} \mathrm{pI}$, predicted isoelectric point of the polypeptide encoded by the PmPR 10 cDNA clones. ${ }^{\mathrm{c}}$ Corresponding PmPR 10 protein spots as detected in Fig. 4 based on pIs and MM.

\begin{tabular}{llll}
\hline PmPR10 cDNA & $\mathrm{MM}(\mathrm{kDa})^{\mathrm{a}}$ & $\mathrm{pI}^{\mathrm{b}}$ & Protein spot $^{\mathrm{c}}$ \\
\hline PmPR10-1.1 & 17.9224 & 5.94 & Group I (a, b, or c) \\
PmPR10-1.2 & 17.8944 & 5.94 & \\
PmPR10-1.3 & 18.0105 & 5.58 & Group II (d, e, f) \\
PmPR10-1.4 & 18.0225 & 5.58 & \\
PmPR10-1.5 & 18.0205 & 5.58 & \\
PmPR10-1.6 & 17.9945 & 5.58 & \\
PmPR10-1.7 & 17.9645 & 5.58 & \\
PmPR10-1.8 & 17.8975 & 5.56 & \\
PmPR10-1.9 & 18.0155 & 5.56 & \\
PmPR10-1.10 & 18.0015 & 5.56 & \\
PmPR10-1.11 & 18.0265 & 5.55 & \\
PmPR10-1.12 & 17.9644 & 5.55 & Group III (g, h, or i) \\
PmPR10-1.13 & 17.7912 & 5.30 & Groun \\
\hline
\end{tabular}

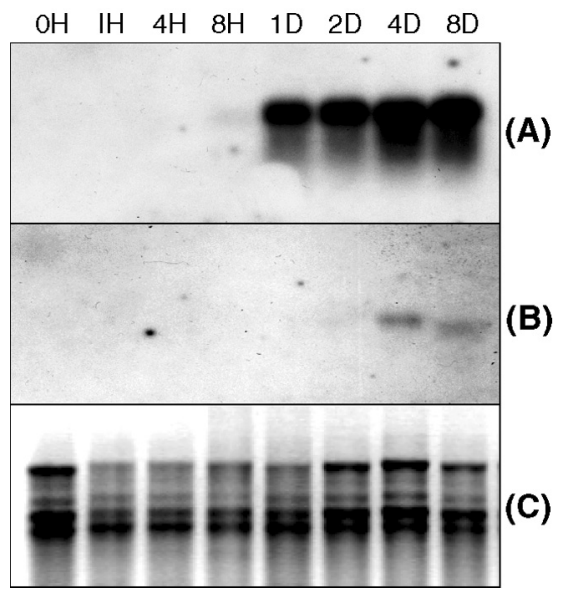

Fig. 2. Northern blot analysis of PmPR10 gene expression in western white pine needles following wounding treatment. Total RNA was extracted from wounded needles with multiple sites and from unwounded needles from wound branches. The tissue samples were harvested at the indicated times post-wounding $(\mathrm{H}$, hours; $\mathrm{D}$, days). (A) and (B) X-ray film images of northern blots from wounded and unwounded needles to show local and systemic responses, respectively. Ten micrograms of total RNAs in each lane was hybridized with a $3^{\prime}$-UTR probe from PmPR10-1.5. (C) An ethidium bromide-stained gel is shown as a loading control.

In contrast to results from local response after wounding treatments, mRNA accumulation of PmPR10-1.5 and related PmPR10 genes in the unwounded needles from systemic wounded branches did not begin until 4 days after treatment and remained at very low levels 8 days after wounding (Fig. 2.B). A shorter PmPR10 transcript was observed in 8 days than in 4 days after treatment for an unknown reason. Activation of PmPR10 genes occurred much earlier and was much stronger for the local response in wounded needles than those for systemic response in the unwounded needles from wounded branches. Whereas the systemic wound response has been well characterized with respect to the production of defence-related products such as proteinase inhibitors, this, to the best of our knowledge, is the first report of systemic accumulation of a PmPR 10 transcript in response to wounding.

\section{Induction of PmPR10 proteins in response to wounding}

To investigate the kinetics of PmPR 10 protein induction following wounding, we performed time course experiments. Local versus systemic responses and single versus multiple-wounding treatments were evaluated. As shown in the western immunoblot analysis (Fig. 3), PmPR10 protein was not detected at time 0 (control), consistent with our previous report that PmPR10 protein was barely detectable in the summer months (Ekramoddoullah et al. 1995). In needles with multiple wounding, PmPR10 proteins were first detected at 1 day and displayed a progressive accumulation up to 8 days, the longest time point we tested (Fig. 3A). In needles with a single wounding, the profile of PmPR10 protein accumulation 


\section{Post-wounding period (Days)}
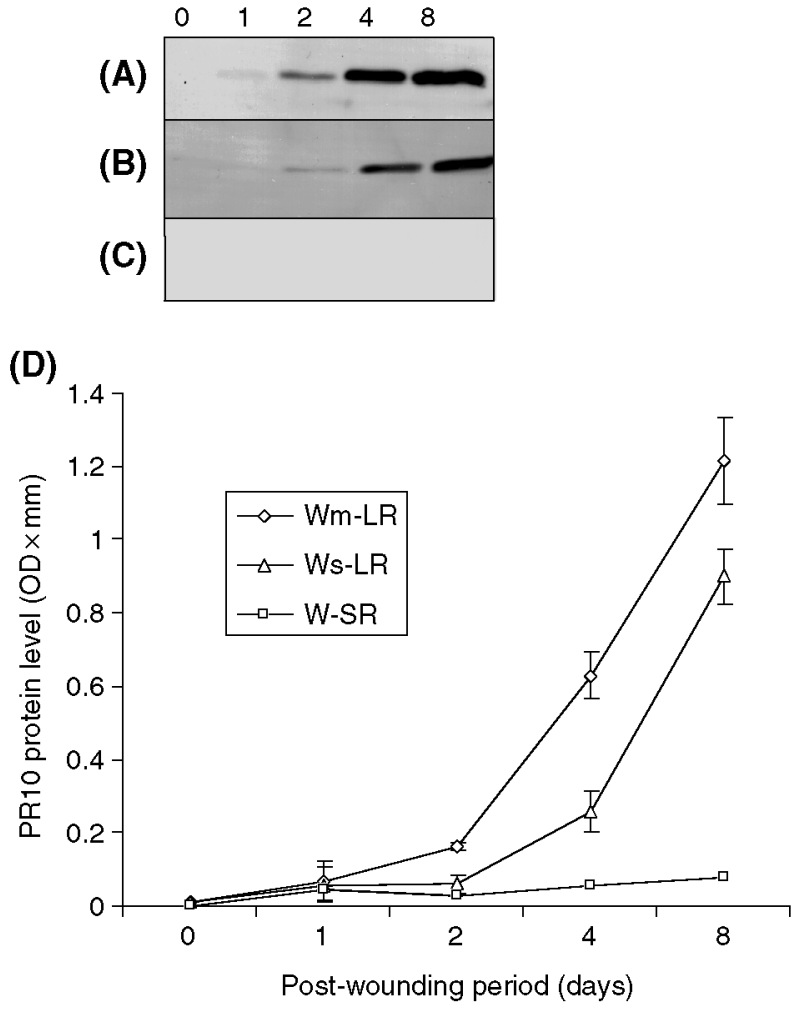

Fig. 3. Wound induction of PmPR10 protein accumulation in western white pine needles. Total soluble proteins were extracted from tissues collected on different days following wounding. Western immunoblot analyses were performed to show PmPR 10 protein accumulation after different wounding treatments. (A) WmLR: local response after wounding treatment with multiple sites; (B) Ws-LR: local response after wounding treatment with single site; and (C) W-SR: systemic response after wounding treatment. Ten micrograms of total protein was loaded in each lane, separated by electrophoresis on SDS-polyacrylamide gels, blotted to PVDF membranes, and analysed using an antiserum against the N-terminal region of a PR10 protein (Pinl I) from sugar pine. (D) PR10 protein levels were quantified using Quantity One software. Each point represents the means $( \pm \mathrm{SE})$ of three independent experiments.

was generally parallel to that for multiple wounding, but the induction was delayed and protein level lower at all times (Fig. 3B). Although a low level of PmPR 10 mRNA was detected in unwounded needles 4 and 8 day after systemic wounding (Fig. 2B), the PmPR10 protein level was probably too low to be detected in the same needle samples even 8 days after treatment (Fig. 3C). Taken together, these results demonstrate that PmPR10 protein expression is activated in response to mechanical damage. The wound-induced PmPR10 protein level is related to the extent of wounding on each needle and displayed a dose-dependent effect. Generally, the induction pattern of the PmPR 10 proteins observed on western immunoblot analyses is in agreement with the accumulation pattern of PmPR10 transcripts following wounding. These comparison data from plants that received different treatments suggest that the wound- inducible PmPR10 protein accumulation may be regulated at the transcriptional level.

\section{Differential regulation of multiple PmPR 10 proteins in response to wounding}

Because a set of PmPR10 cDNAs was cloned from wounded needles (Table 1), we speculated that multiple PmPR10 proteins were also synthesized upon wounding. The single immunostained band observed in western immunoblot analysis of SDS-PAGE (Fig. 3) is likely to be composed multiple polypeptides of similar molecular masses but possessing different isoelectric points (pI). To determine this, western immunoblot analyses were performed following protein electrophoresis on IEF gels or 2-D gels. As shown in Fig. 4A, six bands were detected on the IEF blots after wound induction. On 2-D blots a similar pattern of PmPR10 proteins was detected except that the first and sixth bands on the IEF blot were separated into two and three spots, respectively (Fig. 4B and E). According to their pI values, the wound-inducible PmPR10 proteins can be classified into three groups, each containing three PmPR10 spots (Fig. 4B and E). Group I with pI about 5.9-6.0 includes PmPR10 spots $\mathrm{a}, \mathrm{b}$ and c. Group II with pI about 5.5-5.6 includes PmPR10 spots d, e and f. Group III with pI about 5.2-5.3 includes PmPR10 spots $g, h$ and i. Image density analysis showed that the PmPR 10 proteins in group II were the dominant ones, accounting for about $68 \%$ of the total wound-inducible PmPR10 proteins. Group I and III accounted only for 19 and $13 \%$, respectively. Most PmPR10 cDNAs identified in this study encoded proteins corresponding to the PmPR10 protein spots in group II. PmPR10-1.1 and PmPR10-1.2 encoded PmPR10 proteins corresponding spots in group I and PmPR10-1.13 encoded a protein from group III (Table 1$)$. This was partially confirmed by the recombinant Pin $\mathrm{m}$ III protein (PmPR10-1.10) expressed in E. coli, whose pI and MM values on IEF and 2-D blots fell in the same range as that observed in group II (data not shown). Because of the high polymorphism of PmPR10 gene family in western white pine, it is difficult from our current data to determine exactly which PmPR10 cDNA encodes which PmPR10 protein. The pIs and molecular masses of some predicted PmPR10 proteins are very close to each other (Table 1); therefore, some PmPR10 protein spots identified on 2-D blots, especially those in group II, may be mixtures of PR10 proteins translated from different mRNAs. In summary, the results of cDNA cloning and protein immunodetection demonstrate that multiple PmPR10 proteins are expressed differentially in response to mechanical damage.

\section{Differential regulation of wound-inducible PmPR10 proteins in response to wounding, cold hardening and disease-infection}

Low temperature is one key factor in the cold-hardening process. Therefore, we analysed the accumulation of 


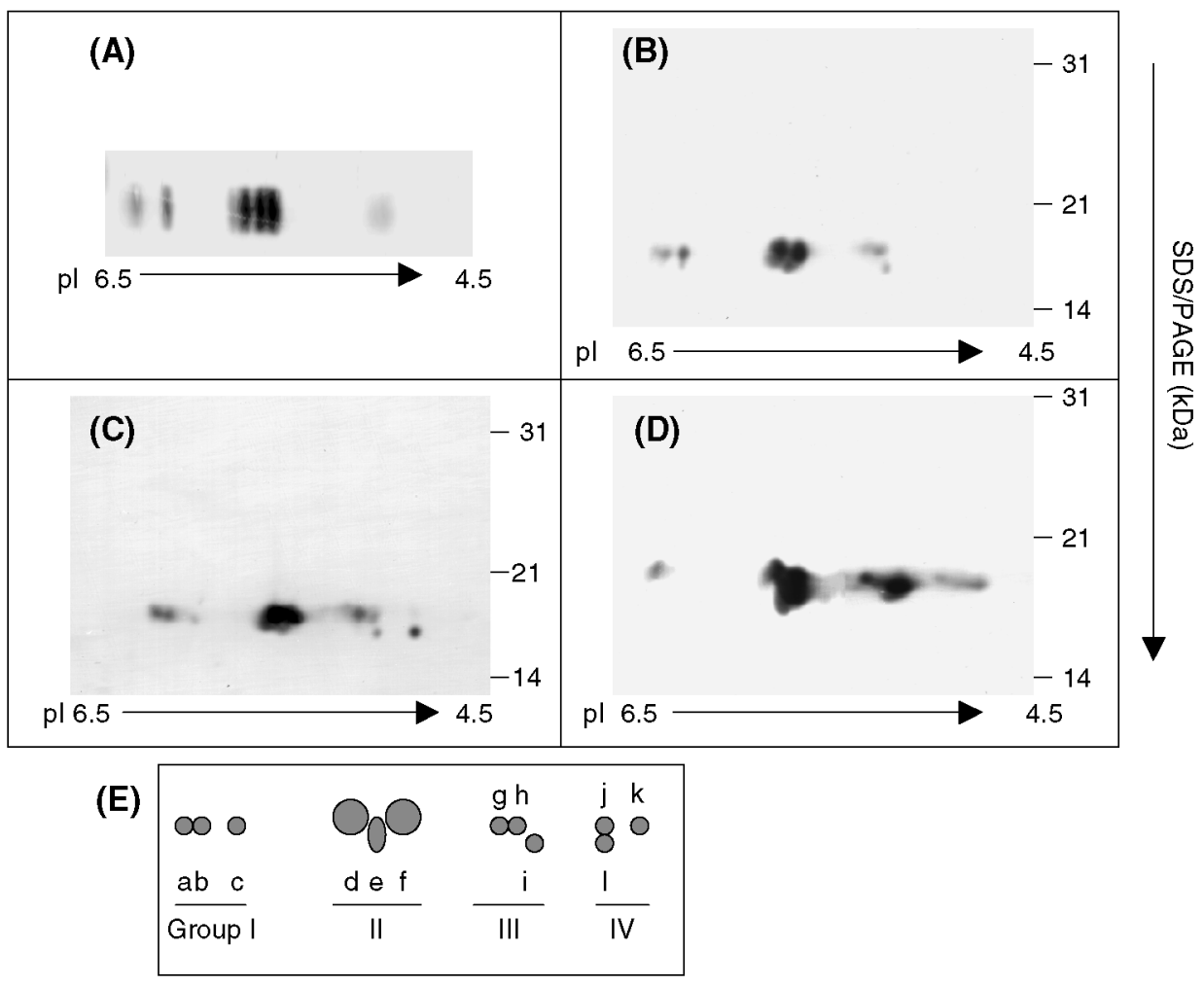

Fig. 4. Comparison of PmPR10 protein profiles induced by wounding, cold-hardening and fungal infection of western white pine by C.ribicola using immunodetection after IEF or 2-D PAGE. Only the area corresponding to $\mathrm{pH}$ gradient from 4.5 to 6.5 , where PmPR 10 proteins are detected, is shown. Proteins were extracted from needles 4 days after wounding treatment with multiple sites, and then detected after IEF (A) and 2D PAGE (B). (C) PmPR10 proteins from summer needles after C.ribicola infection; (D) PmPR10 proteins from healthy needles collected in winter. Fifty micrograms of total soluble proteins was loaded for each IEF gel. Protein transfer and immunodetection were as described in Fig. 3. The pI and position of each PR10 spot was determined relative the migration of protein standards and recombinant Pin $\mathrm{m}$ III protein from E.coli. (E) A schematic representation of PmPR10 protein profiles summarized from (B), (C) and (D).
PmPR10 protein after low temperature treatment $\left(5^{\circ} \mathrm{C}\right)$ under controlled experimental conditions. Western immunodetection of SDS-PAGE blots showed that low temperature $\left(5^{\circ} \mathrm{C}\right)$ did induce PmPR 10 protein expression; however, the PmPR10 protein levels in the tissues exposed to cold $\left(5^{\circ} \mathrm{C}\right)$ in controlled conditions were lower than in tissues collected in winter, infected tissues, or wounded tissues (Fig. 5). These experiments indicate that the temperature change could account for, at least partially, the accumulation of PmPR10 proteins in western white pine in the autumn and winter.

To investigate the expression of multiple PmPR 10 proteins under different environmental stresses, we further compared the profiles of PmPR10 proteins extracted from needle tissues after wounding, blister rust (C.ribicola) infection and winter cold-hardening. These analyses showed that PmPR10 protein profiles were different for different environmental stresses (Fig. 4B, C and D). The PmPR10 protein expression profile in response to cold hardening during winter was more diverse than that evoked by wounding. In addition to the three PmPR10 groups induced by wounding, a group IV with pI about 5.0-5.1 was detected, which include two PmPR10 spots j and k (Fig. 4D). PmPR10 proteins in group II and III were up-regulated, but only one PmPR10 protein spot (a, b or c) in group I was detected in healthy needles after winter cold hardening. In the fungus-infected needles from the summer the PmPR10 protein profile was almost the same as that in wounded needles, only one new PmPR10 protein (spot l) was detected in the $\mathrm{pI}$ range of group IV. PmPR 10 protein spots a, g and 1 were up-regulated, whereas spot c was down-regulated upon infection by C.ribicola (Fig. 4B and C). The PmPR10 proteins in group II were always the dominant ones in the above three cases.

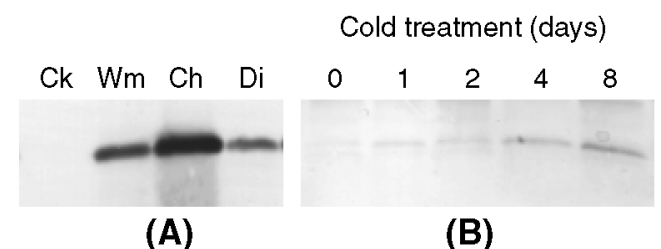

Fig. 5. Western immunoblot analysis of PmPR10 protein accumulation in western white pine needles following different environmental stresses. Protein transfer and immunodetection were as in Fig. 3. (A) PmPR10 protein induced by wounding, cold hardening in winter and fungal infection. Twenty micrograms of total proteins was loaded in each lane. $\mathrm{Ck}$, healthy needles without treatment collected in August of 2000 as control. Wm, healthy needles 4 days after wounding treatment with multiple sites collected in August of 2000. Ch, healthy needles after cold hardening collected in February of 2000. Di, diseased needles infected by C. ribicola collected in August of 2000. (B) Accumulation of PR10 proteins upon cold treatment at $5^{\circ} \mathrm{C}$ in western white pine needles. Fifty micrograms of total proteins was loaded in each lane. Total proteins were extracted from needle samples at different times following cold treatment. These experiments were repeated at least twice with similar results. 
Western immunoblot analyses of 2-D blots established the complex differential expression pattern for PmPR10 proteins in western white pine needles, demonstrating that different members of the PmPR10 gene family are differentially regulated upon different environmental stresses.

\section{Effects of MeJA, SA, ABA and OA on the accumulation of wound-inducible PmPR10 proteins}

PmPR10 proteins are induced upon wounding, fungal infection and cold hardening, which suggests that they may play an important role in the plant defence response. However, no direct evidence is available on the signalling pathways or components regulating their expression in western white pine. To study the characteristics of wound-activation of PmPR10 protein synthesis, the responses to global defence-related signal compounds and OA were investigated. As shown in Fig. 6, western immunoblot analysis shows the time courses of accumulation of PmPR10 proteins in multiple-wounded needles

(A)

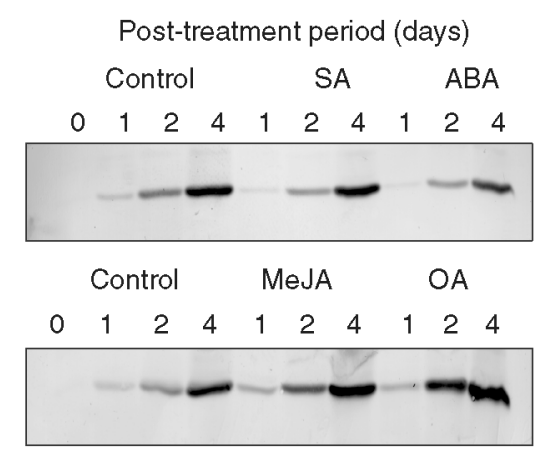

(B)

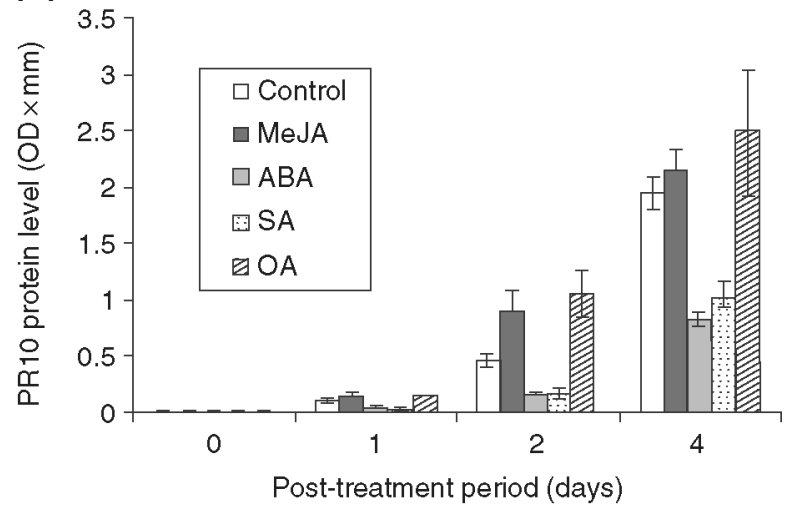

Fig. 6. Effect of treatments with SA, ABA, MeJA and OA on the wound-inducible accumulation of PmPR10 proteins. (A) PmPR10 protein was determined by western immunoblot analysis of SDSPAGE. Protein transfer and immunodetection were as in Fig. 3. Wounded needles were treated for the indicated periods without (control) or with $100 \mu M \mathrm{SA}, 100 \mu M$ ABA, $1 \mu M$ MeJA, or $1 \mu M$ OA. Proteins were extracted and $20 \mu \mathrm{g}$ were loaded in each lane. (B) Relative PR10 protein levels were quantified using the QUANTITY ONE software. Each point represents the means ( $\pm \mathrm{SE}$ ) of three independent experiments. treated with or without chemicals (MeJA, SA, ABA and $\mathrm{OA})$. MeJA at $1 \mu M$ stimulated the accumulation of PmPR10 protein within 2 days of treatment. The enhancement of the wound-induced accumulation of PmPR10 protein by MeJA continued for 4 days, the longest time period analysed (Fig. 6), suggesting that JA or MeJA may act as a signal chemical in western white pine. Compared with the controls (mock treatment, wounding only), the treatment with $1 \mu M$ OA also resulted in increased accumulation of the PmPR10 proteins. Okadaic acid is a membrane-permeable inhibitor of serine/threonine phosphatase type 1 and type $2 \mathrm{~A}$ (Cohen et al. 1990). The increased PmPR10 protein level by OA suggests that hyper-phosphorylation of one or more target proteins may be involved in the signal transduction pathway of the defence response to wounding in western white pine as that observed for potato PR10a (Després et al. 1995).

By contrast, ABA and SA, both at $100 \mu M$, partially suppressed the accumulation of PmPR10 protein after wounding (Fig. 6). All of these chemical treatments affected the level of PmPR10 proteins, but did not change the expression pattern of PmPR10 proteins detected on IEF blots (data not shown). These results suggest the involvement of signal components of plant defence in western white pine PmPR10 gene expression. All of the wound-inducible PmPR10 proteins are also induced by fungal infection, suggesting that cross-talk between the pathogen signalling pathway and the wound response pathway may be present. But the similarity of the PmPR10 protein profiles between wounded needles and winter needles is much more lower (Fig. 4B and D). These observations imply that different signal transduction pathways might be involved in the activation of different PmPR10 genes in response to different environmental stresses.

\section{Discussion}

Our interest in the role of PmPR10 proteins in the plant defence response led to the investigation of their expression upon wounding stress. Many biotic and abiotic stresses can activate PR10 gene expression in plants. PR10 proteins have been shown to be induced by elicitors (Walter et al. 1990, 1996), pathogens (Swoboda et al. 1995, Ekramoddoullah et al. 1998), copper stress (Utriainen et al. 1998), salt stress (Moons et al. 1997), cold acclimation (Ekramoddoullah et al. 1995) and drought stress (Dubos and Plomion 2001). We showed that PmPR10 transcripts accumulated after wounding treatments (Fig. 2). Similar observations have been reported for an asparagus PR10 gene (AoPR1) (Warner et al. 1992, 1993) and for the PR10a gene in potato (S.tuberosum) (Constabel and Brisson 1992, Després et al. 1995).

Comparison of PmPR10 expression showed the different PmPR10 protein profiles in the needle tissues upon wounding, cold-hardening and fungal infection (Fig. 4). The impact of different environmental stresses on plants 
is not well understood. Different stress factors may have both positive and negative effects on plant defencerelated gene expression. Some PmPR10 proteins were expressed to higher or lower levels in response to fungal infection and winter environmental stimuli relative to the levels expressed after wounding (Fig. 4). PmPR10 protein was induced to the highest level by winter cold-hardening (Fig. 5A), but induced to much lower levels by a controlled low temperature of $5^{\circ} \mathrm{C}$ (Fig. 5B). Similar to the synergistical induction of some other low temperatureresponsive proteins in angiosperms, our results suggest that the accumulation of PmPR10 proteins in winter might be caused by the combined effects of many environmental factors, such as temperature and photoperiod.

Some angiosperm PR10 proteins have been reported to have ribonucleolytic activity (Moiseyev et al. 1994, 1997, Bufe et al. 1996, Swoboda et al. 1996, Bantignies et al. 2000). The structure of birch pollen Betv1 determined by X-ray and NMR indicate that its P-loop structure resembles a motif found in many nucleotide-binding proteins (Gajhede et al. 1996). The P-loop sequence is conserved in all PmPR10 proteins as well as in the PR10 proteins from other species. Sugar pine PR10 protein (Pin 1 I) (Ekramoddoullah et al. 1995) was accumulated in needles and 10 PmPR10 proteins were induced by infection with blister rust fungus (Fig. 4). Immunocytochemical localization showed that the PmPR10 proteins were bound to the cell wall of blister rust fungus both intracellularly and extracellularly in the western white pine needles (Ekramoddoullah, unpublished data). This observation implie that the PR10 proteins are synthesized and released from the host cells damaged by the fungus penetration, suggesting their defence role(s) to pathogen attack. Although there is as yet no proof for a ribonuclease function for PmPR10 protein, such proteins with possible ribonuclease activity expressed in the plant defence response may play an important role in injured plant cells, or in pathogen cells after their penetration into plant tissues.

Multiple members of the PR10 gene family are differentially expressed under different environmental stresses (Fig. 4) or at different stages during plant growth and reproduction (Breiteneder et al. 1989, Crowell et al. 1992 , Warner et al. 1993, Swoboda et al. 1995, 1996, Walter et al. 1996, Huang et al. 1997). The multigenic characteristic of PMPR10, as seen in many other genes in plants, indicates that gene duplication and subsequent diversification has occurred during the evolution of the PR10 gene family. This may explain the induction of a large number of PmPR10 proteins under different environmental conditions (Fig. 4). It is therefore not reasonable to assign a unique function to all PR10 proteins throughout the plant kingdom. The functional analysis of different PR10 proteins is very important for us to understand their physiological roles in plants. During evolution of a multiple gene family, different members may have been co-opted to perform an additional function. In winter rye PR3 family two cold-responsive PR3 protein chitinases have been identified with ice-binding activity (Yeh et al.
2000), but other members of this family are pathogeninduced with only enzymatic activity. Previously we observed that expression levels of PmPR10 proteins were correlated with frost-hardiness of foliage in western white pine (Ekramoddoullah et al. 1995). However, the physiological roles of PR10 proteins in cold acclimation are still unclear. The Pin $m$ III (PmPR10-1.10) gene has been transformed into Arabidopsis to investigate the effect of PmPR10 gene expression on frost-tolerance in transgenic plants.

Acknowledgements - This research was funded by CFS-Canadian Biotechnology Strategy Fund awarded to A.K.M.E. The authors are grateful to $\mathrm{Mr}$ Byron Allen (Supported by Government of Canada Youth Internship Program) and Ms Jing Cai for the excellent technical assistance and two anonymous reviewers for helpful suggestion.

\section{References}

Bantignies B, Séguin J, Muzac I, Dédaldéchamp F, Gulick P, Ibrahim R (2000) Direct evidence for ribonucleolytic activity of a PR-10-like protein from white lupin roots. Plant Mol Biol 42: $871-881$

Bowles DJ (1990) Defense-related proteins in higher plants. Annu Rev Biochem 59: 873-907

Breda C, Sallaud C, El-Turk J, Buffard D, de Kozak I, Esnault R, Kondorosi A (1996) Defense reaction in Medicago sativa: a gene encoding a class 10 PR protein is expressed in vascular bundles. Mol Plant- Microbe Interact 9: 713-719

Breiteneder H, Hoffmann-Sommergruber K, O'Riordain G, Susani M, Ahorn H, Ebner C, Kraft D, Scheiner O (1995) Molecular characterization of Api $\mathrm{g}$ 1, the major allergen of celery (Apium graveolens), and its immunological and structural relationships to a group of 17-kDa tree pollen allergens. Eur J Biochem 233: 484-489

Breiteneder H, Pettenburger K, Bito A, Valenta R, Kraft D, Rumpold H, Scheiner O, Breitenbach M (1989) The gene coding for the major birch pollen allergen Betv 1 is highly homologous to a pea disease resistance response gene. EMBO J 8: 1935-1938

Bufe A, Spangfort MD, Kahlert H, Schlaak M, Becker WM (1996) The major birch pollen allergen, betv1, shows ribonuclease activity. Planta 199: 413-415

Cohen P, Holmes CF, Tsukitani Y (1990) Okadaic acid: a new probe for the study of cellular regulation. Trends Biochem Sci 15: $98-102$

Constabel CP, Brisson N (1992) The defense-related $S T H-2$ gene product of potato shows race- specific accumulation after inoculation with low concentration of Phytophthora infestans zoospores. Planta 188: 289-295

Crowell DN, Maliyakal EJ, Russell D, Amasino RM (1992) Characterization of a stress-induced, developmentally regulated gene family from soybean. Plant Mol Biol 18: 459-466

Després C, Subramaniam R, Matton DP, Brisson N (1995) The activation of the potato PR10a gene requires the phosphorylation of the nuclear factor PBF-1. Plant Cell 7: 589-598

Dixon RA, Païva NL (1995) Stress-induced phenylpropanoid metabolism. Plant Cell 7: 1085-1097

Dubos C, Plomion C (2001) Drought differentially affects expression of a PR-10 protein in needles of the maritime pine (Pinus pinaster Ait.) seedling. J Exp Bot 52: 1143-1144

Ekramoddoullah AKM, Davidson JJ, Taylor D (1998) A protein associated with frost hardiness of western white pine is upregulated by infection in the white pine blister rust pathosystem. Can J For Res 28: 412-417

Ekramoddoullah AKM, Taylor D, Hawkins BJ (1995) Characterization of a fall protein of sugar pine and detection of its homologue associated with frost hardiness of western white pine needles. Can J for Res 25: 1137-1147

Ekramoddoullah AKM, Yu X, Sturrock R, Zamani A, Taylor D (2000) Detection and seasonal expression pattern of a pathogenesisrelated protein (PR-10) in Douglas-fir (Pseudotsuga menziesii) tissues. Physiol Plant 110: 240-247 
Farmer EE, Ryan CA (1990) Interplant communication: airborne methyl jasmonate induces synthesis of proteinase inhibitors in plant leaves. Proc Natl Acad Sci USA 87: 7713-7716

Fristensky B, Horovitz D, Hadwiger LA (1988) cDNA sequences for pea disease resistance genes. Plant Mol Biol 11: 713-715

Gajhede M, Osmark K, Poulsen FM, Ipsen H, Larsen JN, Joost van Neerven PJ, Schou C, Løwenstein H, Spangfort MD (1996) X-ray and NMR structure of Betv 1, the origin of birch pollen allergy. Nature Struct Biol 3: 1040-1045

Huang JC, Chang FC, Wang CS (1997) Characterization of a lily tapetal transcript that shares sequence similarity with a class of intracellular pathogenesis-related (IPR) proteins. Plant Mol Biol 34: $681-686$

Lo SCC, Hipskind JD, Nicholson RL (1999) cDNA cloning of a sorghum pathogenesis-related protein (PR-10) and differential expression of defense-related genes following inoculation with Cochliobolus heterostrophus or Colletotrichum sublineolum. Mol Plant-Microbe Interact 12: 479-489

Matheus YN, Ekramoddoullah AKM, Lee SP (2000) Isolation and characterization of transcripts encoding putative intracellular pathogenesis-related protein from cold hardened white spruce tissues. 6th International Congress of Plant Molecular Biology, June 18-24, 2000, Quebec, Canada. NRC Research Press, Ottawa, Canada, Abstract\# S31-71

Matton DP, Brisson N (1989) Cloning, expression and sequence conservation of pathogenesis-related genes transcripts of potato. Mol Plant-Microbe Interact 2: 325-331

Midoh N, Iwata W (1996) Cloning and characterization of a probenazole-inducible gene for an intracellular pathogenesis-related protein in rice. Plant Cell Physiol 37: 9-18

Moiseyev GP, Beintema JJ, Fedoreyeva LI, Yakovlev GE (1994) High sequence similarity between a ribonuclease from ginseng calluses and fungus-elicited proteins from parsley indicates that intracellular pathogenesis-related proteins are ribonuleaes. Planta 193: 470-472

Moiseyev GP, Fedoreyeva LI, Zhuravlev YN, Yakovlev GE (1997) Primary structures of two ribonucleases from ginseng calluses. New members of the PR-10 family of intracellular pathogenesisrelated plant proteins. FEBS Lett 407: 207-210

Moons A, Prinsen E, Bauw G, Montagu VM (1997) Antagonistic effects of abscisic acid and jasmonates on salt stress-inducible transcripts in rice roots. Plant Cell 9: 2243-2259

O'Donnell PJ, Calvert C, Atzorn R, Wasternack C, Leyser HMO, Bowles DJ (1996) Ethylene as a signal mediating the wound response of tomato plants. Science 274: 1914-1917

Peña-Cortés H, Albrecht T, Prat S, Weiler EW, Willmitzer L (1993) Aspirin prevents wound- induced gene expression in tomato leaves by blocking jasmonic acid biosynthesis. Planta 191: 123-128

Peña-Cortés H, Sánchez-Serrano JJ, Mertens R, Willmitzer L, Prat S (1989) Abscisic acid is involved in the wound-induced expression of the proteinase inhibitor II gene in potato and tomato. Proc Natl Acad Sci USA 86: 9851-9855

Ryan CA (1990) Protease inhibitors in plants: genes for improving defenses against insects and pathogens. Annu Rev Phytopathol 28: 425-449

Sambrook J, Fritsch EF, Maniatis T (1989) Molecular Cloning: A Laboratory Manual, 2nd edn. Cold Spring Harbor Laboratory, Cold Spring Harbor, NY
Somssich IE, Schmelzer E, Kawalleck P, Hahlbrock K (1988) Gene structure and its in situ transcript localization of pathogenesis-related protein 1 in parsley. Mol General Genet 213: 93-98

Swoboda I, Hoffmann-Sommergruber K, O'Ríordáin G, Scheiner O, Heberle-Bors E, Vincente O (1996) Bet v, 1 proteins, the major birch pollen allergens and members of a family of conserved pathogenesis-related proteins, show ribonuclease activity in vitro. Physiol Plant 96: 433-438

Swoboda I, Jilek A, Ferreira F, Hoffmann-Sommergruber K, Scheiner O, Kraft D, Breiteneder H, Pittenauer E, Schmid E, Vicente O, Heberle-Bors E, Ahorn H, Breitenbach M (1995) Isoforms of Bet $\mathrm{v}, 1$, the major birch pollen allergen, analyzed by liquid chromatography, mass spectrometry, and cDNA Cloning. J Biol Chem 270: 2607-2613

Titarenko E, Rojo E, León J, Sánchez-Serrano JJ (1997) Jasmonic acid-dependent and - independent signaling pathways control wound-induced gene activation in Arabidopsis thaliana. Plant Physiol 115: 817-826

Utriainen M, Kokko H, Auriola S, Sarrazin O, Kärenlampi S (1998) PR-10 protein is induced by copper stress in roots and leaves of a $\mathrm{Cu} / \mathrm{Zn}$ tolerant clone of birch, Betula pendula. Plant Cell Environ 21: 821-828

Van Loon LC, Pierpoint WS, Boller T, Conejero V (1994) Recommendation for naming plant pathogenesis-related proteins. Plant Mol Biol Rep 12: 245-264

Vanek-Krebitz M, Hoffmann-Sommergruber K, Laimer D, Camara M, Susani M, Ebner C, Kraft D, Scheiner O, Breiteneder H (1995) Cloning and sequencing of Mald I, the major allergen from apple (Malus domestica), and its immunological relationship to Betv 1, the major birch pollen allergen. Biochem Biophys Res Commun 214: $538-551$

Walter MH, Liu JW, Grand C, Lamb CJ, Hess D (1990) Bean pathogenesis-related (PR) proteins deduced from elicitorinduced transcripts are members of a ubiquitous new class of proteins including pollen allergens. Mol General Genet 222: 353-360

Walter MH, Liu JW, Wünn J, Hess D (1996) Bean ribonulease-like pathogenesis-related protein $(\mathrm{Ypr} 10)$ display complex patterns of developmental, dark-induced and exogenous-stimulusdependent expression. Eur J Biochem 239: 281-293

Warner SAJ, Scott R, Draper J (1992) Characterization of a wound-induced transcript from the monocot asparagus that shares similarity with a class of intracellular pathogenesisrelated (PR) proteins. Plant Mol Biol 19: 555-561

Warner SAJ, Scott R, Draper J (1993) Isolation of an asparagus intracellular PR gene (AoPRI) wound-responsive promoter by the inverse polymerase chain reaction and its characterization in transgenic tobacco. Plant J 3: 191-201

Yeh S, Moffatt BA, Griffith M, Xiong F, Yang DSC, Wiseman SB, Sarhan F, Danyluk J, Xue YQ, Hew CL, Doherty-Kirby A, Lajoie G (2000) Chitinase genes responsive to cold encode antifreeze proteins in winter cereals. Plant Physiol 124: $1251-1263$

Yu X, Ekramoddoullah AKM, Misra S (2000) Characterization of Pin $m$ III cDNA in western white pine. Tree Physiol 20: 663-671 